\title{
UNIVERSITYOF
}

FORWARD

THINKING

WESTMINSTER用

WestminsterResearch

http://www.westminster.ac.uk/westminsterresearch

Fucking Law (A New Methodological Movement)

Brooks, V.

This article is (C) Emerald and permission has been granted for this version to appear here: http://westminsterresearch.wmin.ac.uk/20856/

Emerald does not grant permission for this article to be further copied/distributed or hosted elsewhere without the express permission from Emerald Group Publishing Limited.

The final, published version in Journal of Organizational Ethnography, 7 (1), pp. 31-43, 2018 is available at:

https://dx.doi.org/10.1108/JOE-09-2017-0043

The WestminsterResearch online digital archive at the University of Westminster aims to make the research output of the University available to a wider audience. Copyright and Moral Rights remain with the authors and/or copyright owners.

Whilst further distribution of specific materials from within this archive is forbidden, you may freely distribute the URL of WestminsterResearch: ((http://westminsterresearch.wmin.ac.uk/)).

In case of abuse or copyright appearing without permission e-mail repository@westminster.ac.uk 


\section{Fucking Law (A New Methodological Movement)}

Victoria Brooks, University of Westminster (for Journal of Organizational Ethnography)

This paper sets the groundwork for a new methodological movement. I claim that methodological strategies must take as their object the laws with found sexual identity, or rather should be 'fucking with' law by creatively confronting, occupying and agitating limiting ethical frameworks that control access to the field. The movement is ethnographic, since it finds research ethics and 'straight' academic space' to be where these rules are the most harmful in limiting access to the field, for female researchers in particular. The approach (but also to some extent the target) is Deleuzian and postDeleuzian philosophy whose theoretical leaps have sought to shift and cause slippage in laws of sexual identity. However, when these laws are tested by researchers proposing to access the field, specifically ethnographically and autoethnographically, it is clear they have not 'slipped' at all. This is clear through the questions raised by ethics committees. Fucking law therefore becomes a methodological movement intimately connecting ethical agendas and sex as an encounter in the field. I claim the methodological movement of 'fucking' law captures, or at least attempts to capture, the slipperiness of the body, the encounter, the research project and sex itself. The movement that is 'fucking law' is essential in agitating and occupying not only philosophy, but limiting institutional research agendas and their ethical frameworks. The implications of 'Fucking Law' will be necessarily unpredictable, but the main practical and connected social implication is a questioning as to why more women are not practically questioning arguably one of the biggest questions: the ethics of sexuality. Fucking law argues for the questioning of these laws with bodies, and experimenting with philosophies which underpin and create institutional ethical rules.

\section{Introduction}

In sexuality research, the challenge for a participatory researcher is: how far should 'l' go, or rather, how far is it ethical to go? The more pressing question, I would argue, is how far is it ethical to step back. I claim here that the answer to this question levelled at a researcher in the sexuality field goes to the core of ethical questions at every level of the sexual research encounter: methodologically, philosophically and nonphilosophically (or personally). My claim is that undertaking ethical research in this field demands a new, brave, sensitive, confrontational and slippery fucking methodological movement. 'Fucking Law' is a methodological movement embodied by the individual body of the researcher. It is a movement that acknowledges the philosophical, methodological and philosophical and non-philosophical lines which traverse this individual body, while also letting, encouraging and empowering that same body to push, agitate and urgently question these lines. 
In sexuality research these ethical questions are urgent. I am among a statistically small group of women carrying out participatory research in the field of sexuality, ${ }^{1}$ and this is concerning. The urgency of this situation cannot be overstated, since while philosophy and method have taken a radical, critical and feminist turn, presence within the field itself, has not. This brings me to ask, why are there so few of us here? De Craene (2017) in relation to sexual geography fieldwork, has suggested that this may be because of a certain 'discomfort' associated with the complexities of being a woman researcher. I claim that this 'discomfort' is at the core of why radical, fluid, sensitive and provocative methods are required in this field, which probe at, and seek the origins and academic consequences of this 'discomfort'. This is a crucial endeavour, since this discomfort is only the beginning, with the weighty consequence of such reactions being that this reticence feeds into the construction of sexuality work as 'dirty work' thereby limiting the range of bodies taking part, and inhibiting the production of, and funding for production of, sexual knowledge (Irvine, 2014).

During this paper, I find that the reason for this is that entering the field of sexuality as a woman is hard. It is ethically hard - both institutionally and personally. Carrying out sexuality work is consistently to be the 'rebel' or the one people in your department are unsure of how to 'react to', in the face of consistent 'deep cultural anxieties about [this area] of study' (Irvine, 2014). This position arises from cultural anxiety, but also personal anxiety, since with the announcement of 'I do participatory sexuality work' comes the suggestion that I have a clear connection (troubled or otherwise) with sex, which could either titillate or often in my experience, produce discomfort in others, as well as in myself because of their reaction. Newton (1993) already predicted these kind of issues, with the advent of the female sexual fieldworker, comes the swirling uncertainties of their sexualities; having once been the absorber (or partner) of the male anthropologist, she now suddenly has her own sexual agency and investment in the field. How terrifying it must be for those who encounter us, how difficult it must be to not know which end of the spectrum of female identity we are at: whether we are angelic, pure and objective, or rather whores, unable to resist our dissolution into encounters. Consequently, women are also unable to benefit from the 'veil of professional silence' that exists towards men who have casual sex with women in the field (Newton, 1993). As Dubisch (1995) has noted from her personal experience, it is often the inclination of those engaging with the female researcher, that she has no desire for encounters with male bodies in the field. As the author goes on to say, it would be even more outrageous were she to write about such an attraction or encounter (Dubisch, 1995).

What flows from this is the most problematic of all concerns, that it appears to be a 'radical' position to write about emotional, individual and sexual 'draws' to the field as

\footnotetext{
${ }^{1}$ By 'this field' I mean in the participatory ethnography, and the ethics of sexuality in particular. The field sadly shrinks further when narrowing to a focus on the legalities and ethics of the broad field of sexuality.
} 
part of the field (Moreno,1995). The field is thus not only the physical space entered by the researcher, but the whole milieu, that is, the researcher's body, the academic institution of which the researcher is part, the physical space of the field, and the emotional and sexual body, of the researcher and other bodies in the field.

The clear tension reverberating through the bodies of female researchers in the sexuality field, and the field itself, is as problematic as it is illuminating. I argue that this space is created by the legalities of the research encounter. These legalities are the most visible and obvious actualization of all the tensions female researchers have identified: research ethics. Research ethics are not only institutional, but as I shall argue, also highly personal. This institutional and personal difficulty in entering the field originates from a fundamentally legal place. It is research ethics that place before us the embodied reality of the philosophical laws of the body. These translate into the methodological and ethical laws which malign the body even before it thinks of entering the field, which make it stop. Dead. Le petite mort tempers and pacifies the pre-orgasmic researcher body before she can even contemplate the encounters she seeks to sketch, understand and write. Even if such a body manages to remain aroused and step into the field, the proverbial ice-cube will quell any possibility of finding the truth of sexuality, since law will not leave her in peace, to fuck peacefully.

I shall go on to argue throughout this paper that in the name of those of us who, against the odds, against law, against ethics, against institution, against lovers, have entered the sexuality field, that we need to start 'fucking law'. This is to create the path for others to continue preventing the institutional marginalization of sexuality work (Irvine, 2014). I shall argue that every 'against' is a movement toward a law that needs to be 'fucked'. Fucking is the only way, since 'against' is not vociferous enough to translate these into research (and pedagogical) agendas. Fucking is the slippery business of connecting sexual practice with social pejorative, with institutional agitation, with ethical agenda, with finally, the perturbation of the oppressive philosophical foundation of heteronormative identities and laws of the body.

\section{Fucking Philosophy}

And love, where all is easy, Where all is given in the instant; There exists in the midst of time

The possibility of an island. ${ }^{2}$

The 'first' level of fucking perhaps the most obstinate of encounters. While it is arguably easy to fuck anywhere, there is nothing so difficult to shift than the internal,

2 Houellebecq (2006) 
philosophical 'laws' of the body. Post-structural philosophy such as that of Deleuze and Guattari has long since taken the body away from stability, Cartesian separation and Kantian morality, riding on a Spinozan wave to open the possibility for embodied ethics (Lambert, 2006). Embodied ethics empower the body, to make its own 'decisions' through the ethical demands of 'encounters' (Grear, 2011; PhilippopoulosMihalopoulos, 2015). Feminist thought has radicalised this position and radically sexualised this position, with the joining of voices from a variety of philosophical disciplines. In relation to law, the legal body is both vulnerable and empowered (Grear, 2011). Feminist scholars have argued robustly against the stability and rationality of the assumed legal subject, as incompatible with the onto-ethical demands of the feminist project, and built the legal body as not exclusively human (Fineman, 2012). The legal body has been 'freed' by philosophy, or so we are told. The legal body has moved from a categorised amalgam of legally owned 'parts' (Hyde, 1997) toward a body which is as radical, slippery and volatile as the philosophy which found this to be wrong. Authors such as Elizabeth Grosz are heavy-weight presences in creating the theoretical anti-Cartesian conditions for the mere possibility of this resistance too, through the revolutionary re-situation of the feminine body as inherently productive, as well as disruptive, of epistemological regimes created through traditional understandings of the body, space and time, as well as sexuality (Grosz 1994; 1995). In terms of law however, there is a difficulty in terms of legal personhood specifically in limiting the feminine body's capacity to be empowered against and with legally imposed/assumed vulnerabilities, together with the ethics of productive corporeal empowerment. Critical legal thought has brought the body closer to a philosophically free body. Therefore it is clear that only through interdisciplinarity has law even invited the possibility of being 'fucked' (confronted, agitated, provoked) into revising the ways it judges and defines bodies.

We have seen from Irvine (2014) that academia, the quintessential philosophical space and arguably the natural research space, remains constrained by law, with sociologists doing sexual work reporting an absence of training, structural support and passive disparagement of their field, stigmatization, and the perception that quantitative methods are more valuable. Further than this, this kind of marginalization stretches forth from a molecular institutional level, toward a macro (US) governmental level with the blocking of funding for so-called 'risky' sexuality work (Irvine, 2014). Here we see the instantiation of the necessity of the interdisciplinarity of legal critique, as well as resistance. Law would have us respect the judgments of those in power in institutions and government, those with the authority of law and the power to make decisions and set academic, pedagogic and research agendas. Despite the clear radicalization of law and the critique of body-defining laws and identities, these laws have not shifted, nor stopped exercising their power in response to the sexuality of women.

This is even more apparent when one enters, or attempts to enter the field and explicitly test and target these 'new' interdisciplinary ways of thinking the body, the 
response of ethical regimes within academic institutions suggest that these laws have not slipped at all. I am still part of a tiny minority of women testing sexual ethics with their bodies. How can this be? I can only find that philosophical thought has not taken the body far enough. May the position be more disturbing that we thought. Perhaps those philosophical laws are so deep, so resolutely internalised and spread through the blood of the body that they stop the body moving - no matter how radical - the 'cock of greasy philosophy', dead, weeping, protruding from every philosophy (Rhymbu, 2016). ${ }^{3}$ The closest we come to escaping the shackles is to look at how this philosophy makes us move, and it is my claim that the ethics flowing from these philosophical laws would have us stop at the threshold of participation. However, Preciado took these philosophies and fucked them $-\mathrm{s} /$ he entered the field, charted his/her journey with unflinching detail and undertook the bravest of projects - to find where her individual sexuality was traversed by what is not hers through embodied radical philosophical practice (Preciado, 2013). S/he begins her journey by setting the agenda by opening with Derrida's 'amusing' statement as to what he would like to see in a documentary on Heidegger, Kant, or Hegel: 'for them to talk about their sex life' (Preciado, 2013). Immediately we find the playfulness and the confrontational effect of the sexual: suddenly, philosophy is fucked, but only through the fucking of philosophers.

It has long since been found (by philosophers) that philosophy cannot be separated from bodies that think and create their concepts (Deleuze and Guattari, 2011). This conjoining was framed as subverting the Cartesian idea that separates concepts as disconnected instruments of reason from the bodily workings of thinking itself. Concepts therefore grow and develop with the body that uses them as tools, such that the concepts themselves are embodied and performed and mixed with the flesh of researchers. This is liberating, yet also alarming in view of the problematic instantiation of law as power in academia. The laws might therefore be more open to 'fucking' through institutional agitation, but they are also obstinate. Preciado fucks him/herself from the very start, attesting to the only possibility of overcoming the penetration of the cock of greasy philosophy through fucking it right back. We must find then that there is both a connection and a distance between a sexual life and philosophy, and that a definite move is required to enter, and to agitate, the relation between fucking and philosophy. We, who are interested in overcoming and agitating these laws, must become fucking philosophers: the 'fucking theories' cannot save us (Rhymbu, 2016).

\footnotetext{
${ }^{3}$ Extract from Rhymbu's 'Sex is a Desert'

'...the dead cock that protrudes from every philosophy

Alain Badiou fucking theories, numbers, a weeping member, the cock of greasy philosophy what are you good for, if you could only save us...'
} 


\section{Fucking Method}

Nothing. Waiting. Then, an extraordinary lucidity settles in, gradually, accompanied by a desire to fuck, walk, go out everywhere in the city... My body is present to itself. $^{4}$

Those thinking the field have also tried. Fucking has started to become the vestige of radical researchers. Bell called urgently for geography to be 'fucked' (Bell, 2009). He dared to say, 'fuck you', and directed a powerful and playful provocation at his field. He finds power in the word 'fuck' which of course, in most cases will prevent publication or presentation within all but the most radical academic arenas (Bell, 2009). Bell attributes this fear to not only banal academic conservativism, but a deeper fear of the slipperiness of the body, and the messy materiality of bodies (Bell, 2005). The word 'fuck' is provocative to be sure, but it is as slippery as the encounter it linguistically reflects. To say fuck, is to ask the other to contemplate the possibility of being fucked: confronted, titillated, rendered unintelligible, perhaps joyous, perhaps destabilised, and at worst, emotionally or physically suffering. Fucking is not necessarily positive, nor is it necessarily negative. Rather, it is the movement that is necessary in the face of an academic environment that is prone to marginalize sexuality work, and/or prioritize quantitative methodological approaches. It seems that so long as there is distance between the researcher and sex, in research endeavor and in presentation of research, then those in power can rest. Fucking refutes this distance, and says yes to explicit connection to sex as that which happens in the field, no matter the identity of the researcher, and yes to the connection between this and sexual knowledge production.

Methodological thinking has begun to take this radical turn. Sexuality research has been called a 'research assemblage' by Fox and Alldred, meaning that the researcher must be seen as entering into a relation with the bodies of the field as part of an event, and not distanced, objective bodies using their tools upon 'objects' (Fox and Alldred, 2013). This position finds the very act of being situated a methodological position in itself, and for the registering and understanding of sexual encounters as a particular kind of assemblage. This, although becoming a conceptual tool for the researcher, does not help us with the ethics of participation. For if we are to say that we are situated among a sexuality assemblage, how far can our relations extend, in the name of 'research' - in short, what are the ethics of such an assemblage, being intimately connected to these bodies and then fucking?

If the decision as to participation in sexuality research seems to be such a dilemma, as pioneers such as Dean, Preciado and Irvine (discussed above) have found, then it becomes an ethical call in itself to account for that decision in the course of radical

\footnotetext{
${ }^{4}$ Preciado (2013)
} 
sexuality ethnographic work (Dean, 2009; Lambevski, 1999). Letting in the nonphilosophical in this way has itself become controversial, and in need of radical account. Playing with data is not a new position to take. Hofness and Sonenberg and Honan have already found the necessity on the back of the tenets of radical philosophy to open the horizons of data (Hofsess and Sonenberg, 2013; Honan, 2007). Opening data's horizons means accepting its inherent multi-directional instability, and the effect of the researcher on transfiguring data into 'new lines of flight' (Hofsess and Sonenberg, 2013).

What is new here, is the possibility of combining new ways of conceiving of the life of data, but also combining this with the sexual_life of the researcher. It is autoethnography as a methodological plane that has begun explicitly do this, and to allow the researcher themselves to track their personal investment in the ethics of sexuality, together with their theoretical, academic and methodological journey (Brooks, 2016). It seems though, that in the field of sexuality and participatory methodologies, the field is depressingly small, especially when it comes to autoethnographers, and miniscule when it comes to female autoethnographers. The exception could be Stein, albeit her study concerned a record of the ethics of writing of other's sexuality, rather than hers specifically (Stein, 2010). It is not surprising, however, when we read of Stein's experiences and discomforts (Stein, 2010). At the threshold of sexual participation, the feminine self seems to retreat to text, and I find that given my own experience, there are good reasons for this fear of fucking. This fear is sometimes created and wielded by the creators of those very concepts that have become the laws of our bodies.

\section{Fucking Philosophers}

after falling in love with you, why is she so interested in this sexuality... coming back to the male issue, she said that there is something in your behavior that makes her worried for me, that there is something quite male in you ${ }^{5}$

Geographers entering the field of sexuality are predominantly men. Despite the huge leaps forward driven by feminist thinking, De Craene, and indeed I, felt we must justify our positions as female researchers in sexuality research. Further than this, I too apparently 'needed' a dose of masculinity before I began my own autoethnographic project. I needed to be called a man, or my sexuality needed to be called male, and my research endeavor needed to be called a leap toward what he called 'sexual freedom' and confined to my 'male sexuality'. These suggestions that I am making, are precisely at the core of the ethical urgency for law to be fucked, and in the coming paragraphs I shall make a claim as to why.

\footnotetext{
${ }^{5}$ Extract from correspondence from my philosopher lover in November 2014 upon my return from my fieldwork at the nudist beach at Cap D'Agde in July 2014.
} 
Along with others, I have found that sexual encounters generate their own ethics, in accordance with a Spinozan/Deleuzian philosophical foundation. However, I have found that this frame continues to hold the encounter in accordance with law, with the law retaining a 'stamp' on immanent encounters (Philippopoulos-Mihalopoulos, 2015). I have claimed that 'escape' beyond this philosophical frame is necessary, through the performative reality of the Laruellian One (l'un). Laruellian immanence can be a transitionary device, creating the path from philosophy to field, from page to practice, from radical Deleuzian philosophy to living, breathing, performative sexual ethics (Brooks, 2016). The same has been claimed in relation to the potentials of Laruellian philosophy for art/fiction practice (O'Sullivan, 2017).

Laruelle arguably does not advance Deleuzian thinking on the reality of immanence, yet in the field, such an advance is urgently required if we are to look back at the apparently limiting philosophical tenets of even radical methodological approaches to the ethics of participatory sexuality research. I have claimed that Laruelle adds to the immanent plane a possibility for an outside of ethics, a chance for radical difference to be performed by the body through non-philosophy. We must be careful though. 'Nonphilosophy' is dangerously close to philosophy, you only have to look at the name and the author who created it.

Before, during and after my own autoethnographic sexuality project, I remained a 'threat' somehow to my lover at the time (Brooks, 2016). My lover was a philosopher, and so was I (albeit reluctantly). I mean this in the literal sense, in that we were both academics in the field of law and philosophy, but also in the sense that we were contemplating the ethics of our own encounter. Upon me, I found imposed (repeatedly) a version of my identity that did not belong to me. Flowing from this identity, came a perceived ethical threat emanating from the 'mystery' of my sexuality, or my lack of coherence in the face of the assertion of a heteronormative schema. I suggest that the bodies of philosophers are no more adept at being objective than sexuality field researchers. They are no better equipped at determining the laws or sexual ethics of the body, than any-body who has sex, yet it is these laws that I, and I am sure others, find repeatedly asserted; by our judges whether they be lovers or juridical.

My own sexual work encounter was with plage naturist in Cap D'Agde ('the Cap') (Brooks, 2016). This was a theoretical (Deleuzian and post-Deleuzian thought) as well as applied project, where unexpectedly, method and research ethics became the significant focus. When I say research ethics, I mean both institutional and personal. It was the ethical challenges of my personal sexual encounters that I found traversed by legalities, or collective ethics. For this project, I visited the nudist beach at the Cap in July 2014 for a three-week period (this was peak season where the site welcomes in the region of 40,000 visitors, some of which take part in open public sex on the beach and among the dunes, often with multiple partners) (Brooks, 2016). During this project, I produced a 'field diary' which recorded and reflected upon my encounters at 
the Cap. I chose this auto-ethnographic method precisely because it would hold the potential to bridge the gap between individual and collective, or otherwise allow my 'ethnography to discover the individual' (Muncey, 2010). In this way, I could bring my intensely personal sexual ethical dilemmas into my project and find where they were traversed by collective legalities and effects of identities.

My lover raised a salient point, though. Why then, was I there? The answers to this question are complex and deeply theoretical, and which I have attempted to answer elsewhere (Brooks, 2016). The important aspect for Fucking Law, is that nonphilosophical transparency is essential in agitating the deepest philosophical tenets of sexuality. The questions between my lover and I were as old as humanity itself, but why was the asking of these questions so violent? Why was my presence there so frightening? I found that interrogation of this question is enriched through turning at the same time toward the institution's objections to my entry onto the field.

De Craene (2017) has carried out vital work in the field of geography, where she has recognized both the problematic position of female researchers in sexuality research in the field of geography, and the necessity of addressing this: 'After all, the absence of the lusty researcher's body has methodological, epistemological, and political consequences and therefore disciplines the production of knowledge, also within critical sexuality studies' (De Craene, 2017). I join her voice resolutely and humbly and say that the kind of movement the author is advocating is precisely what is needed. De Craene points to the problematic confluence of emotional and academic forces, which converge to produce legal conflicts in terms of gendered and sexual identity. The author also points unflinchingly toward the ethical stakes involved in disclosing our desires, as researchers. These ethical stakes might involve the success of our academic careers, and conjoined with this, I claim, the extent to which we can ever understand sexuality. De Craene (2017) is situated right in front of the line, at the precipice of fucking law, by fucking ethics:

transgressing different norms on what constitutes as 'good research' (i.e. body work and sexuality) does not come without risks, as it involves giving up a position of privilege and involves a degree of emotional labour which might be crossing boundaries of what a researcher might be motivated or required to do in order to achieve a certain degree of epistemologically, ethically and methodologically sound research (p461). 


\section{Fucking Ethics}

'...you just documenting people fucking and men masturbating but it does not do anything more to you anymore, but how am i supposed to feel, it is all simple for you on the white warm sand'6

It is the frank interrogation of the link between philosophy and body (personal ethics) and research ethics (institutional ethics) that allow for the possibility of fucking law, or otherwise of understanding, exploring and playing with identity and its impossible grasp of the slippery sexy body.

Any project that is by association with the researcher part of an institution will need to go through the requisite 'ethical approval' processes. My own project, although eventually approved, much to the credit of my institution and careful engagement by its Research Ethics Committee, underwent close scrutiny. The ethical scrutiny it received revealed some much-treasured legalities of feminine sexuality.

The concerns of the Ethics Committee were as follows:

- The Committee have serious concerns about your safety given you will be working off-campus with negligible support in a potentially dangerous environment where individuals nearby could be actively seeking a sexual encounter.

- The Committee were unclear how you would record the observations, for example would you propose relocating to improve the quality of your observations, and if so how would you be able to guard against suspicions being raised about your activity. Is it possible to undertake covert observations in this way and at the same time remain inconspicuous? ${ }^{7}$

- Concepts of privacy could be contentious. While the research will be undertaken on a public beach, the individuals being observed may view their area as being a private or semi-private space. As there are quite strict laws in France relating to privacy has there been any assessment of the legality of the proposed research in the local context? Can you

\footnotetext{
${ }^{6}$ Extract from correspondence from my philosopher lover in July 2014 during my fieldwork at the nudist beach at Cap D'Agde.

${ }^{7}$ At all times I ensured that my note-taking was inconspicuous, that all data was anonymised and that my presence as researcher was never revealed. I have also avoided graphic description of encounters in case of any possibility of any identification or unease. I would also like to thank many members of the Law School at the University of Westminster for their assistance in drafting and considering the response to the Committee, particularly concerning the 'privacy' aspect in the next concern listed, where consideration of strict French privacy laws was required.
} 
confirm that any proposed covert observations will only take place on people who are in a space that could be reasonably be observed by others, the individuals would have no expectation of privacy and that you will not follow individuals to better observe them should they go behind bushes/into caves, etc.?

- Have you considered recruiting "Key Informants"? i.e. recruit users of these areas as a means of reducing safety concerns, however, it is recognised this would have an impact upon your proposed methodology and may provide less satisfactory data. ${ }^{8}$

I found in the course of the writing-up of this project that these very legal concerns are somewhat disingenuous, since they stem from a much deeper fear of the subject matter: sex, or rather, fucking. The ethical schemata, as revealed by my judges (the Committee members themselves) are based on decision-making frameworks that comprise metrics of merit and integrity, justice, beneficence and respect (Halse, 2011). I claim that these do not constitute an ethical frame, but a legal frame. The Committee presides in a particular context which renders it ethical, since its decisions relate directly to, and are contingent upon, a projected encounter. However, the co-ordinates set out in Halse's example which relate to a highly sensitive (fictional) context of married men and their use of child prostitutes, are unethical. Halse goes on to critique the strictly moral basis of these decisions and suggests that greater scrutiny be given in the light of the neo-liberal self-interested space of the academic institution (Halse, 2011). The author writes:

As with other national ethics guidelines, an ethical framework of principlism is not based on a single, coherent ethical theory but a set of practical principles that draw on an amalgam of philosophical perspectives: Kant (autonomy); Rawls (justice); Mills (beneficence); and Gert (nonmaleficence) (p242).

Halse points to the 'universal philosophical' underpinning to Ethics Committee decisions, which take for granted the basis on which the legal person is formed. This 'taking for granted' rests at the core for the need for 'fucking ethics', not just an ethics of fucking. There is nothing in this institutional 'ethical' framework which indicates its decisions will be truly 'ethical' in the context of the complex philosophically and legally inhibited field that is sexuality. To be ethical in this context entails connection, as well as faithfulness to the field.

The Ethics Committee is of course compiled of bodies. Institutional bodies, and creators of concepts (legalities) which as critical scholarship has found, are

8 These passages are lifted directly from the initial decision by the Ethics Committee. See Correspondence (decision and my response) at Appendix 1 of Brooks (2016). 
predominantly 'straight' (Bolton, 1995) This term is not used in the heterosexual orientation sense, but rather as the antithesis of 'queer'. Halse (2011) felt the need herself to make a 'confession' as to this reality. This indeed should be applauded, but the question comes as to the harmfulness of this reality, and indeed what to do about it.

This is where I make my claim to occupation of academic space, and translate that into a call for the fucking of law, as a methodological movement directed at research ethics and a particular legality of sexuality, and obstruction to the field. David Bell says in an interview on his essays that 'fucking' was initially part of his work as firstly a 'playful provocation', but also somewhat of a 'joke', stemming from a desire to confront his discipline and express his exasperation (Silva and Vieria, 2010). This brave gesture is no joke. Or rather, it may be, but it is one of those 'jokes' which carry with it significant truth. The Ethics Committee's power to have potentially stopped my project, and the abuse from my lover at the time, is no joke. I do not mean this simply in terms of personal suffering, but more in the consistent concealment, denial and lack of deep understanding and sensitive questioning as to the truth of sex. Without fucking, this truth will remain 'concealed and censored', with researchers doing sexual work disadvantaged professionally, promoted and funded unequally, and subjugated by institutional ethical bias (Irvine 2014).

It was clear too that the legalities of identity reared their head again, with a transparent fear as to whether I might be a sex-crazed woman, a 'pervert', or I might be a naïve pure woman, where they are responsible for protecting me against corruption. This 'treasuring' of such heteronormative identities must stop because it is a symptom of not only straight academia, but a conservative and restrictive agenda that is actively inhibiting research, as sending the message that it is 'OK' to judge those doing sexual work. As Irvine (2014) found, some academics have refused to work with respondents due to perceived 'unethical' practice and 'immorality'. These perceptions of academia are legal: flowing from the philosophical laws of the body and folding into ethical institutional agendas.

Bell was expressing a desire to fuck 'with' geography, and I say that my desire is to fuck (with) law. To fuck as a researcher, questioning and studying sexuality, to 'mess' with law, by confronting it with its ethical basis, or the encounters from which it gains its rules and its strength, and which it treats as its court - or that which must be judged. Bell finds that geography could not be fucked, and that 'shock' at his vocabulary was absorbed (Silva and Vieria, 2010). My methodological suggestion though is not fuck law, but fucking law. Indeed, it is the case, that people stop listening. It may be the case already that my fucking in this text has become banal, indeed annoying. But this is the very point. The shock comes, inevitably within the academic discipline, and my suggestion is that it will never be acceptable to fuck. But, there are infinite points along the research process and within the academic space where the shock will be felt, and reflection, introspection, violence and possibility, will inspire change. 


\section{What is fucking law?}

The presence of sex within fucking law is as mysterious as the matter of sexuality. An impossible fish to catch, observe or measure, as I found in my study of law's relationship with sexuality (Brooks, 2016). I suggest there are 'four folds of fucking': Fucking Philosophy; Fucking Method, Fucking Ethics and finally, Fucking Law. We have seen above the necessity for Fucking Philosophy (in not taking for granted philosophical definitions and prescribed movements of bodies, even if they come from radical philosophy). We have also seen the necessity and basic groundwork for Fucking Ethics and Fucking Method, above, but what then, is Fucking Law? What are we trying to do and how does it look as a concrete research agenda?

Fucking law is a movement, which flows from the researcher's body and resonates through the research process (from the choosing of a philosophical framework, through ethical approval, and through non-philosophical expression and action in the field) where it occupies unexpectedly, provocatively and sensitively. The researcher must become at once impetuous (Silva and Vieria, 2010) but also transgressive (De Craene, 2017). This is not transgression in a banal sense, but in a broader, bigger and vital sense: the recognition and intricate negotiation of ethical lines.

I make no claim that I am the first to fuck law. I do not claim that autoethnography is the only way to be fucking law - it is but only one possible path. There are researchers all around me fucking in all manner of different ways, and we are starting to become radically annoying. Agitators. Those such as De Craene, Bell, Binnie and Preciado are at the vanguard, and all I seek to do is join their voices and add to their song, which I hope to be written delicately across research agendas and ethical frameworks in this field.

A vital instantiation of fucking law is, as De Craene has noted, the call for introspection and examination of the researcher's situatedness within the assemblage (Fox and Alldred, 2013). It is introspection and confrontation combined provocatively toward research ethics, and a call to occupy the neo-liberal, self-interested space that is 'straight' academia (Binnie, 2009). The word 'fucking' still hangs, provocatively unfolded as to its precise addition (aside from provocation) to my methodological claim. Perhaps it should remain unfolded and holding loosely its slippery meanings to fuck (with). It is clear though, that fucking with academia is necessary, even at the linguistic level. I have, like Bell, been told to remove the word 'fuck' from the titles of my work, with claims that this kind of language would be potentially 'offensive'. ${ }^{9}$ There

\footnotetext{
9 I have had a similar experience as David Bell in relation to 'fucking' titles. A recent publication of mine (after extensive correspondence) was permitted, but not until the 'fuck' was changed to a 'f\#ck'.
} 
is a call here that returns us to the beginning of my piece here - that philosophy and its modes of expression require intervention.

This is a further aspect of fucking law. The ethical call is that of seeking out the modes through which philosophy is embodied, and how far the researcher's body is traversed by these lines, and whether it can, comfortably, emotionally, sexually, intellectually, practically, and ethically move differently. Law's reach into the identity of researchers and the way in which it judges encounters, can be done away with, only through performance, feeling and action. The lines might be 'right' and this is a possibility we must accept too, but not so readily - we must play. Fucking law is to have done with judgment, and seek the rebuilding of the courtroom, restore the fucking anarchic encounter to itself (Deleuze, 1997; Brooks, 2014). This is only facilitated through access to the field, however.

If we are to fuck (with) law, we need geography, we need art, we need science, we need methodology, we need gender, sexuality, culture, environment. We need the fucking of disciplinary boundaries wherever it is possible. The bravery of researchers in other disciplines is staggering - the pioneering work of Binnie, Bell, De Craene and Preciado mean that I could find robust and projects among which to situate my own, and empowerment too, to press ahead at times where the possibility of entering the field seemed remote and too troublesome - both institutionally and personally. There were voices from law too, but the shyness about entering the field of sexuality is undeniable. This is an opening of law, albeit resistant, to the potential of other disciplines to bring challenges to the sexual tenets of its judgments. Critical legal theory tells us that the body is the law's 'battleground', but it is its interdisciplinary which sends the body into battle, fucking law from the ethical inside.

The challenge is whether and indeed how to solidify the movement that is fucking law into a concrete research agenda. I certainly do not make a claim that every researcher must account for their own erotic subjectivities - indeed my own experience is perhaps a case for not doing so, and is why female researchers find themselves vulnerable, and reticent to justify their own desires (De Craene, 2017). As a pointer, as to when, and how to find points of occupation, I return to fucking itself.

\section{An Orgasmic Agenda?}

Fucking law gains the most ground through advocating as intimate as possible connection between the actual field encounter of sex, and the ethical frameworks which govern both access, participation and presentation of research. The intimacy of this connection produces the 'points' of occupation the movement encounters. Sex becomes formative of the agenda, as opposed to its object, it is fucking (with) law. The researcher body may find itself simultaneously held and released by its identity, with its sexual pleasures invested, but also exceeded, problematised and shifted by its encounters (Bell, 2011). It has become increasingly apparent that 'sex' can be 
conceived outside of traditional heteronormative penetration, and can be instead conceived as an 'intensity', or 'consistency' (Deleuze and Guattari, 2004a; Beckman, 2011) that defines the sexuality assemblage (Fox and Alldred, 2013). With a radical conception of sex mobilised by feminist radical thinking, we find a radical way of orienting (or disorienting) the tenets of sexual identity. Instead of defining an encounter's sexuality and its bodies through the site (spatial and temporal) of the male orgasm, we can instead accept that the immeasurable, mysterious, multiple, often invisible female orgasm agitates identities from within. The female orgasm has simultaneously been silenced and misunderstood, as well as endowed with radical potential for intervening in sexual orientation and identity (Beckman, 2013). It is through fucking law, that we can adopt radical and inventive methods of tracing these potentials. The female orgasm has therefore moved from positioned as secondary to male ejaculation, and seen as 'signifying nothing' (Beckman, 2013) to becoming the force behind 'Fucking Law'.

Preciado has found that orgasmic force is genderless, without sexual boundary, without orientation and without confinement to any particular organ: 'the penis possesses no more orgasmic force than the vagina, the eye or the toe. Orgasmic force is the sum of the potential for excitation inherent in every material molecule... It is a source of transformation for the world in pleasure' (Preciado, 2013). When the researcher is faced with such unbounded pleasurable potential, she finds herself the source of ethical genesis. Preciado's potentia gaudendi is within every single molecule of each and every encounter - whether we can see it or not - fucking law comes from agitation at the most microscopic structural level and thereby generates an imperceptible reverberating ethic, within the blood of the researcher, the institution and the encounter itself, which cannot always be written, but must be expressed. Such an agenda is therefore a necessarily shaky one, with ethical questions arising seemingly out of nowhere. Orgasmic investment into the introspection and expression of sexual encounter is therefore the key to fucking with any discipline, as Alhadeff (2011) has found:

Whether I am viewing my process of ejaculation, my becoming, through the uncanny Deleuzian masochist or the Taoist field of immanence, I am positioning myself within intuitive re-configuring of socialised sexuality. The nature of this collaborative emancipatory project transgresses internalised, invisible, taken-forgranted capitalist Oedipal structures. Creativity and subjectivity become pedagogical strategies for social change (p108).

At my PhD viva, I was asked what I would say to a student who was thinking about undertaking a similar project to my own at the Cap. My answer was schizophrenic, since I could not say that I wished the struggles I had endured upon another researcher. But of course researchers must and will, inevitably since potentia gaudendi will take us into the field, again and again. As researchers, we are often teachers, too. Our research is intimately connected to the pedagogic strategies we 
adopt. ${ }^{10}$ In this way, fucking law moves from the researcher to students (the next generation of researchers, or indeed practitioners) encouraging them and pushing them to agitate ethically.

It is not the case that every project will be appropriate to a 'Fucking Law' methodological approach. However, I do suggest that a moment may arise, certainly in many projects which concern sexuality, where law will need a touch of fucking. It may be philosophically, it may be non-philosophically, it may be methodologically, or it may be actually fucking, in the flesh. Fucking Law as an agenda, is difficult to pin down. Difficult as, it might be said, as the female orgasm is to define, occurring at a multitude of expected, and unexpected sites. It could be while reading Deleuze, or it could be at night, after the day's research, it could be at sunrise, or it could be a few months after your PhD viva, or it could be in the classroom. Fucking Law is creative tracing, occupation, provocation, agitation and expression embodied by researchers who will continue to be a nuisance: to their institution, ethics committees, philosophy and quite possibly, their lovers.

\section{Fuck Law}

This sand of 100,000 orgasms, just allowing me to sit, and how I desire just one of those at the hands of just one man, such a curious thing. ${ }^{11}$

Fuck Law. Law won't ever be fucked, but it's the fucking that counts. The movement, towards all the laws that tell us what sex should be like. Within all that mess, all the banality of perversion, all the commodification of what should be ours, behind the profiles, the endless updates, the sticky latex and the cock-rings and dildos, gangbangs, beyond the dunes, under the surface, beyond the philosophy and nonphilosophy, and past the conversation, far beyond the articles and the books, the endless words, the pornography and the dating, moving past even fiction, is the possibility, the faint scent, the before-touch, the shy outline, and morning trace, of a fucking orgasm.

\footnotetext{
${ }_{10}$ My own research and teaching practice has been inspired and influenced by that of my PhD supervisor, who continually involves his students into his research processes and these processes in turn, into his education processes, and so on and on. I express my continuing thanks to Andreas for his gentle and unwavering support and encouragement.

${ }^{11}$ Extract from field diary: 15 July 2014, 6.20am, Brooks (2016).
} 


\section{References:}

Alhadeff, C 'Tongue and Trigger: Deleuze's Erotics of the Uncanny' in Beckman, F (2011)

Beckman, F (ed) (2011) Deleuze and Sex (Edinburgh, Edinburgh University Press)

Beckman, F (2013) Between Desire and Pleasure: A Deleuzian Theory of Sexuality (Edinburgh, Edinburgh University Press)

Bell, D ‘Fucking Geography, Again’ in Browne, K et al (eds) (2009) Geographies of Sexualities: Theory Practices and Politics (Surrey, Ashgate)

Bell, J 'Deleuze and Selfless Sex: Undoing Kant's Copernican' in Beckman, F (2011) Deleuze and Sex (Edinburgh, Edinburgh University Press)

Binnie, J 'Sexuality, the Erotic and Geography: Epistemology, Methodology and Pedagogy' in Browne, K et al (eds) (2009) Geographies of Sexualities: Theory Practices and Politics (Surrey, Ashgate)

Brooks, V (2014) Interrupting the Courtroom Organism: Screaming Bodies, Material Affects and the Theatre of Cruelty, Law Culture and the Humanities, DOI: $10.1177 / 1743872114543767$.

Brooks, V (2016) Ethics Beyond Immanence: Rupturing Law's Method through Sex Research, Doctoral Thesis, University of Westminster

Browne, K et al (eds) (2009) Geographies of Sexualities: Theory Practices and Politics (Surrey, Ashgate)

Dean, T (2009) Unlimited Intimacy: Reflections on the Subculture of Barebacking (Chicago, University of Chicago Press).

Deleuze, G trans. Smith, D and Greco, M (1997) Essays Critical and Clinical (Minnesota, University of Minnesota Press) p131

Deleuze, G and Guattari, F (2004a) trans. Hurley, R, Seem, M and Lane, H, Anti-Oedipus (London, Continuum) p325

Deleuze, G and Guattari, F (2011) trans. Burchell, G and Tomlinson, H, What is Philosophy? (London, Verso) 
De Craene, V (2017) Fucking Geographers! Or the epistemological consequences of neglecting the lusty researcher's body, Gender Place and Culture 24:3 449-464

Fineman, M and Grear, A (eds) (2013) Vulnerability, Reflections on a New Ethical Framework (Farnham, Ashgate)

Fox, N and Alldred, P, The Sexuality Assemblage (2013) The Sociological Review, Vol. 61, p769-789, p774

Grear, A The Vulnerable Living Order: Human Rights and the Environment in a Critical and Philosophical Perspective (2011) 2/1 Journal of Human Rights and the Environment 23-44

Grosz, E (1994) Volatile Bodies (Indianapolis, Indiana University Press)

Grosz, E (1995) Space, Time and Perversion (London, Routledge).

Halse, C (2011) Confessions of an ethics committee chair, Ethics and Education, 6:3, 239251.

Hofsess, B and Sonenberg, J (2013) Enter: Ho/rhizoanalysis, Cultural Studies, 20:10, 1-10

Honan, E (2007) Writing a Rhizome: An (im)plausible Methodology, International Journal of Qualitative Studies in Education, 20:5, 531-546

Houellebecq, M The Possibility of an Island (Phoenix, 2006)

Hyde, A (1997) Bodies of Law (West Sussex, Princeton University Press)

Irvine, J (2014) Is sexuality research 'dirty work'? institutionalized stigma in the production of sexual knowledge, Sexualities 17:5-6, 632-656

Jones, J, Grear, A, Fenton, RA and Stevenson, K (eds) (2012) Gender, Sexualities and Law (Oxon, Routledge).

Kulick, D and Willson, M (eds) Taboo: Sex, Identity and Erotic Subjectivity (Routledge, 1995)

Lambevski, A (1999) Suck My Nation - Masculinity, Ethnicity and the Politics of (Homo)sex, Sexualities, 2:4, 397-419

Muncey, T (2010) Creating Autoethnographies (London, Sage).

Newton, E (1993) My Best Informant's Dress: The Erotic Equation in Fieldwork, Cultural Anthropology, 8, 3-23

O'Sullivan, S 'Non-Philosophy and Art Practice (or, Fiction as Method) in Jon K. Shaw and Theo Reeves-Evisson (eds) Fiction as Method, Berlin (Sternberg, 2017) 
Philippopoulos-Mihalopoulos,A Spatial Justice: Body, Lawscape, Atmosphere (Routledge, 2015) 206

Preciado, Beatriz Testojunkie (Feminist Press, 2013)

Rhymbu, G (2016) 'Sex is a Desert' http://www.thewhitereview.org/poetry/sex-is-a-desert/

Silva, J Vieira, J, 'Fucking Geography': An interview with David Bell, Revista Latino-americana de Geografia e Genero, 12/21/2010, Vol.1(2), pp.318-325

Stein, A (2010) Sex, Truths and Audiotape: Anonymity and the Ethics of Exposure in Public Ethnography, Journal of Contemporary Ethnography, 39:5, 554-568. 